ISSN 2078-6441. Вісник Львівського університету. Серія географічна. 2018. Випуск 52. С. 232-239.

Visnyk of the Lviv University. Series Geography. 2018. Issue 52. P. 232-239.

http:/ / dx.doi.org/10.30970/vgg.2018.52.10189

$55: 338.483 .11$

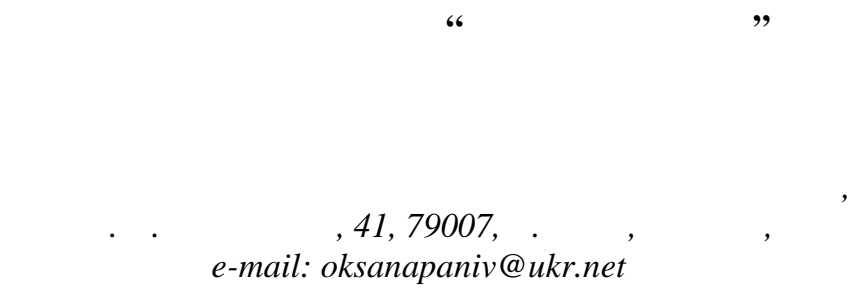

еосп дщин є невід'ємною ч стиною всесвітньої природної сп дщини, як повинн бути збережен для м йбутніх поколінь. оловною цінністю природної сп дщини є н уков інформ ція про риси т процеси еволюції н шої пл нети. жливою рисою природної сп дщини є вст новлені людиною цінності, які можуть змінюв тися з ч сом. еосп дщин м є деяку схожість з історикокультурною сп дщиною, оскільки вон не з вжди пов'яз н з природними простор ми, у б г тьох вип дк х геологічний інтерес може бути тісно пов'яз ний з історико-культурними елемент ми. е ч стин природної сп дщини певної території, яку ст новлять георізном нітні елементи з особливою геологічною цінністю, тобто ті, які повинні бути з хищеними теперішнім і м йбутнім поколіннями. еосп дщин може охоплюв ти як елементи, які з ляг ють н місці утворення, т к і елементи, переміщені з поч ткового місцезн ходження (колекція геологічних зр зків), які м ють п леонтологічну, геоморфологічну, мінер логічну, петрологічну чи стр тигр фічну зн чимість. еосп дщин є об'єктом геотуризму. еотуризм - це порівняно новий термін, який ужив ють для озн чення подорожі, присвяченої осягненню унік льної культури т історії будь-якого регіону, подорожі, метою якої є розширення зн нь геогр фічного х р ктеру про місце, його оточення, сп дщину, культуру і добробут місцевого н селення.

еотуризм тісно пов'яз ний з охороною геосп дщини: 6 г то геотуристичних тр кцій одноч сно перебув ють під пр вовою охороною. т ких вип дк х з пров джують спеці льний режим їхнього відвідув ння - обмежують доступ до цих об'єктів чи окремих їхніх ч стин, скеровують туристичний рух з чітко визн ченими і пром рков ними тр с ми, контролюють туристичне н в нт ження т використовують інші можливі способи для їхнього збереження.

творення вропейської соці ції зі збереження геологічної сп дщини ст ло зн ковою подією міжн родного зн чення. вропі були створені егіон льні робочі групи, до скл ду однієї з них ентр льноєвропейської - н р зі входить і кр їн .

лючові слов : геосп дщин, геоконсерв ція, георізном ніття, геотуризм.

юдин може спостеріг ти лише 3 обмеженою кількістю об'єктів геосп дщини, дже втруч ння в н др земної поверхні призвело до прискореного руйнув ння б г тьох ключових ч стин геологічних свідчень.

еосп дщин є невідновлюв ним природним ресурсом, н який вплив ють людин і природні чинники (н прикл д, звітрюв ння, ерозія, змін клім ту). юдство може призвести до ч сткової бо повної втр ти геологічних об'єктів розвитком містобудув ння, в нд лізмом, відсутністю н лежної пр вової охорони об'єктів геосп дщини тощо.

г лом суспільство не до кінця розуміє в жливість геосп дщини т потребу іiі охорони, незв ж ючи н існув ння б г тьох міжн родних т н ціон льних політик $\mathrm{i}$ стр тегій з хисту біорізном ніття. іжн родні орг ніз ції повинні бути ктивнішими у

(C) нів ., 2018 
визн ченні стр тегій і цілей геозбереження, що в підсумку вплине н природоохоронну політику окремих держ в.

береження геологічної сп дщини ст ло в жливою спр вою у вропі ост нніми десятиліттями. вдяки цьому ідентифіков но сотні об’єктів геологічної сп дщини, які потребують 3 хисту з погляду н уки, освіти і туризму. ніці тиви, спрямов ні н ефективне упр вління цими об'єкт ми, є в жливими сьогодні коли йдеться про екологічну політику і ст лий розвиток. дже нинішня екологічн ситу ція може не тільки ст ти джерелом економічних, соці льних т інших втр т, й призвести до екологічної кризи пл нет рного м сшт бу. ому необхідн систем 3 ходів, спрямов них н 3 безпечення якості н вколишнього середовищ, збереження природної т культурно-історичної сп дщини.

береження об’єктів геосп дщини повинне м ти н лежне визн ння, 3 хист т упр вління елемент ми і л ндш фт ми, які є в жливими з геологічного т геоморфологічного погляду.

кр їні дет льно опис но (у 4-томному путівнику-довіднику “ еологічні п м'ятки кр їни”) 719 об’єктів геологічної сп дщини. ведено опис геологічних п м’яток, що м ють н укову т естетичну цінність, серед яких н йбільше х $\mathrm{p}$ ктерні відслонення гірських порід і форми земної поверхні. е п м’ятки природи, які д ють змогу зрозуміти геологічну історію території кр їни. кож співробітники геолого-розвідув льного інституту ( $\mathrm{kp}$ ) створили просторову б зу д них геологічної сп дщини, як н лічує 642 об'єкти. і об'єкти дет льно опис ні, кл сифіков ні т відобр жені н електронних к рт х геоінформ ційних систем ( ).

йповніше н укові дослідження т пр ктику в г лузі геотуризму, об’єктом якого є геосп дщин , уз г льнено в моногр фії “ еотуризм” (“Geotourism”) 3 ред кцією влінг т . ьюсом (2006) т в н уково-популярному ч сописі “ ео уристик” (“GeoTurystyka”), який виходить у ольщі з 2003 р. уковий журн л “ ео уристик” н укової соці ції т нісл в т сіц вид ють спільно ф культети геології, геофізики т охорони н вколишнього середовищ ірничо-технологічної $\mathrm{K}$ демії. ньому публікують н укові т інформ ційні м тері ли, присвячені всім спект м глоб льного геотуризму.

$m$ меm - визн чити сутність поняття “геосп дщин ", його походження, особливості вжив ння. б’єкт дослідження - природні елементи, які м ють геологічну цінність і можуть слугув ти об'єкт ми геосп дщини т потребують з хистуз поглядун уки, освіти і туризму. редмет дослідження - цінність геолого-геоморфологічних об'єктів т їхня роль у формув нні геосп дщини.

еосп дщин - це сукупність унік льних геологічних елементів н тій чи іншій території, які н очно і повною мірою х р ктеризують перебіг геологічних процесів і м ють н укову т пізн в льну цінність, т кож $є$ доступними для безпосереднього спостереження і дослідження.

еологічні елементи є в жливою ч стиною н шого природного довкілля. х використовув ли, як ресурс від поч тку освоєння людиною земних н др. прикл д, з лізні вироби було зн ряддям пр ці у первісних людей; гірські породи слугув ли для будівництв ; сіль є індик тором морського середовищ н певній території в минулому, т кож iï відд вн широко використовують люди. 
ільшість геологічних об’єктів приверт є ув гу людини, пробуджує інтерес, д є естетичну н солоду. кими геологічними елемент ми є гірські породи, мінер ли, корисні коп лини, структури, природні ресурси геологічного походження (мінер льні родовищ ) і природні процеси.

кщо ж говорити про сутність с мого поняття “сп дщин ”, то з зн чимо, що сп дщин - це сп дкове володіння, це цінності перед ні бо придб ні. тип ми сп дщин може бути: 1) м тері льною бо нем тері льною; 2) рухомою бо нерухомою; 3) прив тною бо публічною.

кщо об’єкт є певною цінністю, то він може фігурув ти як сп дщин . типом цінності сп дщин може бути т кою: н уков, культурн, історичн, економічн , фольклорн , освітня, н вч льн, естетичн, л ндш фтн, містичн, релігійн тощо. ип сп дщини (природної чи культурної) визн ч є елемент, який є незмінним, не цінність, бо вон може змінитися в будь-який момент. тже, геосп дщин - це геологічний елемент з високою цінністю.

ьогодні геосп дщин - це передусім природні відслонення, які н очно демонструють особливості геологічної будови території, т кі як гірські породи, мінер ли, т кож різні п леонтологічні зн хідки, т кі як ск м'янілості, стр тигр фічні послідовності н ш рув нь т різном нітність л ндш фтів, які відобр ж ють звітрюв ння й ерозію в різних клім тичних і тектонічних умов х.

еосп дщин може бути нерухомою, бо рухомою (порт тивною). ерухомі об'єкти геосп дщини можн пок з ти н к рті. окрем, сьогодні їх зобр ж ють 3 допомогою геоінформ ційної системи, як д є змогу поєдн ти модельне зобр ження розміщення об'єкт геосп дщини н території з інформ цією т бличного типу. ухомими об'єкт ми геосп дщини можуть бути зр зки корисних коп лин, які зберіг ють, н прикл д, у музеї.

омилковим $€$ соціюв ння природної сп дщини з історичною бо культурною, тому що корисні коп лини не можуть бути культурною чи історичною сп дщиною. роблем т ких помилкових тверджень у тому, що непр вильно визн чен цінність елементів, оскільки вон змінюється з ч сом.

к невід'ємн ч стин всесвітньої сп дщини, геосп дщин є унік льним відобр женням еволюції н шої пл нети. роте лише обмежен кількість об'єктів геосп дщини доступн для спостереження людьми. своєння людиною поверхні емлі призвело до прискореного руйнув ння б г тьох ключових ч стин геологічних свідчень, як в кр їні, т к і в б г тьох європейських кр їн х.

еосп дщин є ч стиною природної сп дщини і передб ч є дослідження геологічних свідчень життя н емлі, геологічних процесів т розвитку форм рельєфу. йбільш предст вленими геологічними об'єкт ми у списку всесвітньої сп дщини є гірські л ндш фти, вулк ни т к рстові території, тоді як кл сичні геологічні об'єкти, орієнтов ні н ск м'янілості, стр тигр фію бо тектоніку, порівняно рідкісні. к б чимо з рисунк , геосп дщин тісно пов'яз н з історико-культурними елемент ми, одн к геологічні т біологічні об'єкти з йм ють одн кове місце серед природних п м'яток. еосп дщин $\epsilon$ фунд ментом всесвітньої сп дщини, оскільки вон $є$ основою біологічного, культурного т л ндш фтного різном ніття.

сторично скл лось т к, що елику рит нію вв ж ють б тьківщиною геології. он жє лідером у збереженні геологічних п м'яток. кожз поч тков но терміни “геосп дщин " т “геоконсерв ція" [5]. 
кр їни з досить в гомим досвідом у г лузі збереження сп дщини емлі елик рит нія, встр лія). дн к у б г тьох держ в х ідеї т політику геоконсерв ції ще треб розробляти т впров джув ти.

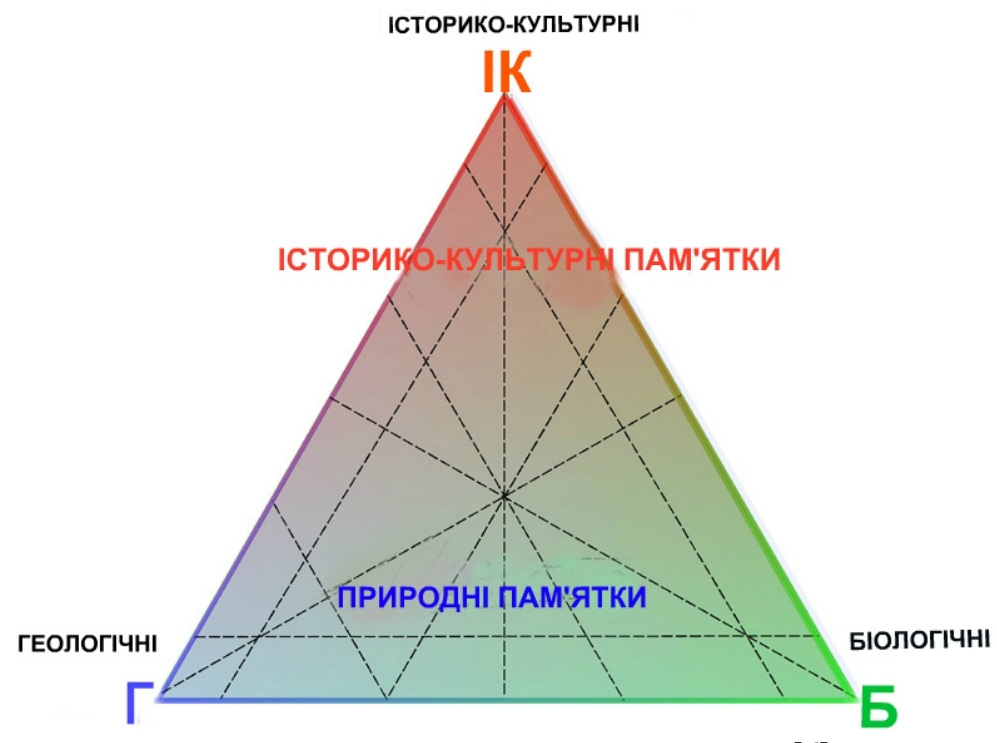

ісце геосп дщини у всесвітній сп дщині [6] Place of geoheritage in the world heritage [6]

іжн родному симпозіумі з охорони геологічної сп дщини у р нції 1991 р. створено вропейську соці цію зі збереження геологічної сп дщини (ProGEO), як рекл мує 3 хист в жливих геологічних об’єктів т л ндш фтів, т кож різном нітну сп дщину геологічних особливостей з н уковою, освітньою, туристичною т культурною кту льністю. цьому ж форумі прийнято “ іжн родну декл р цію пр в п м’яті емлі", основні положення якої т кі:

1. ст в ч с визн ти унік льність емлі, подібно тому, як визн чен унік льність людського життя.

2. ти- емля трим є н с, кожен з н с і ми всі прив'яз ні до неї. он - зв'язок між н ми.

3. емля існує 4,5 млрд років і є колискою життя з усім змін ми і перетвореннями. рив л еволюція сформув л н вколишнє середовище, у якому ми живемо.

4. сторія людств й історія емлі тісно пов’яз ні. ї історія - це н ш історія, іiі м йбутнє - н ше м йбутнє.

5. емля в усіх спект х - це н ше середовище... ми лише тимч сові супутники емлі.

6. одібно до кілець ст рого дерев , емля зберіг є п м'ять про минуле. я п м'ять 3 пис н в гірських пород х і л ндш фт х. я п м'ять може бути прочит н й осмислен людиною.

7. ст в ч с зберіг ння н шої природної сп дщини - середовищ, у якому ми живемо. инуле емлі не менш в жливе, ніж людське існув ння.

8. и і емля володіємо спільною сп дщиною. и і н ші уряди - г р нти цієї сп дшини. сі м ють розуміти, що н йменше іiі розкр д ння - неповторн втр т . 
9. сім н ціон льним і міжн родним орг н м вл ди треб зв ж ти н необхідність охорони геологічної сп дщини всім юридичними, фін нсовими й орг ніз ційними з соб ми [1].

ротягом ост нніх 20 років простежується щор з більший інтерес до геогр фічних н ук $з$ тем ми, пов'яз ними з геосп дщиною, с ме: геоконсерв ції, геотуризму т геоп рків.

роблем тику збереження геосп дщини ктивно розгляд ють н н уково-методологічному і пр ктичному рівнях. ст нніми десятиріччями сформов но низку методологічних підходів з дослідження т конструктивного пл нув ння і використ ння об'єктів геосп дщини. озроблено дослідницький інструмент рій геоконсерв ційного (geoconservation) і геотуристичного (geotouristic) підходів т сформов но з с ди інтегр тивно-конструктивного підходу, в основі якого - поняття георізном ніття (geodiversity). окрем , у геоконсерв ційному підході для вибору т оцінки об'єктів геосп дщини широко використовують т кі концепту льні поняття, як геос йти і геотопи. еос йти визн ч ють як місця особливого н укового інтересу, геотопи - це цінні геолого-геоморфологічні утворення, що охоплюють певну територію. дослідженнях, пов'яз них $з$ георізном ніттям, усебічно розгляд ють пит ння інтегр ції геосп дщини з територі льним пл нув нням т біол ндш фтним різном ніттям. рівні природоохоронної пр ктики в г лузі геосп дщини ре лізують низку міжн родних і н ціон льних прогр м, спрямов них н виділення геос йтів міжн родного зн чення, розширення з повідних к тегорій т створення геоп рків - іннов ційних форм збереження і рекре ційного використ ння геосп дщини [3].

еоконсерв ція н лежить до н ук про емлю, метою якої є збереження сп дщини для н укової чи освітньої цілей. еоконсерв ція, тобто збереження геосп дщини, стосується визн чення, з хисту й упр вління об'єкт ми і л ндш фт ми, визн ченими як т кі, що ст новлять геологічний т геоморфологічний інтерес. еоконсерв ція - це стр тегії і прогр ми щодо збереження георізном ніття і геосп дщини, упр влінські дії (пл нув ння, використ ння), які сприяють збереженню в ч сі певної цінності. пр влінські дії щодо збереження сп дщини потребують з конного з хисту н різних рівнях [5].

еосп дщин і геоконсерв ція - це поняття, пов'яз ні зі збереженням унік льних форм рельєфу, природних і штучних відслонень місць, де можн вивч ти геологічні особливості. б'єКт ми геосп дщини можуть бути ті природні біотичні елементи і процеси, які є об'єктивними з погляду геоконсерв ції. кож геосп дщин охоплює в себе форми рельєфу й інші геоморфологічні особливості, які ілюструють н слідки суч сного т минулого впливу клім ту і сил емлі.

іткої різниці між геологічними елемент ми, георізном ніттям і геосп дщиною нем є, тому дуже ч сто н д ють перев гу термінові “георізном ніття” для всього. дн к геосп дщин і георізном ніття - це різні поняття (з кільком зв'язк ми). тже,

- $\quad$ усі території м ють геологічні елементи;

- $\quad$ території з в жливою геосп дщиною можуть м ти дуже низьке георізном ніття;

- $\quad$ території з високим георізном ніттям можуть м ти не цінну геосп дщину.

еорізном ніття - це природне різном ніття геологічних (мінер ли, гірські породи), геоморфологічних (форми рельєфу, фізико-геологічні процеси) і грунтових особливостей, які є продукт ми еволюції; це різном нітність т розподіл природних біотичних елементів і процесів. р метри елементів георізном ніття зумовлені геогр фічним розт шув нням і ч сом утворення. 
голосимо, що дослідження геосп дщини тр диційно орієнтов не н сільські чи природні регіони, зокрем, природні п рки т геоп рки. н шу думку, міські р йони є недост тньо дослідженими сьогодні. собливо цік вим з погляду геосп дщини є те, що геоморфологічн будов деяких міст є ч стиною їхнього “іміджу" т популярності (н прикл д, укров гор іо-де- нейро).

сновні проблеми досліджень геосп дщини в міських умов х т кі:

- скл дні вз ємозв'язки між природними форм ми рельєфу т міськими форм ми;

- ч стков бо з г льн невидимість форм грунтів і відкл дів, що їх покрив ють, бо руйнують міськими інфр структур ми;

- штучні земельні форми як ч стин міської геоморфологічної сп дщини;

- прид тність деяких форм лісу (долини, яри, кріплення) для конкретних міських потреб;

- форми рельєфу, які спричиняють труднощі для розвитку міст;

- в жливість деяких форм рельєфу для міського л ндш фту й іміджу міст.

ермін “геотуризм” виник у середовищі геологів. еологічний туризм (геотуризм) як новий н прямок туристичних м ндрівок з поч тков ний у 1995 р. й н був міжн родного зн чення в 2001-2002 pp. цінюють, що близько 50 \% туристів у розвинених кр їн х підп д є під к тегорію геотуристів. еотуризм тр ктують як форму туризму, що зберіг $€$ бо н віть розширює пізн в льні, культурні й естетичні перев ги певної території. ін грунтується н основних принцип х збереження х $\mathrm{p}$ ктеру тр кційних геологічних місць (від природних резерв тів до промислових споруд гірничої діяльності), їхнього дружелюбного екологічного способу подорожув ння [4].

жливі об'єкти природної бо культурної сп дщини, які є основою геосп дщини, вносять у список омітету всесвітньої сп дщини

тже, геосп дщин як об'єКт геотуризму створює інтерес до геотуристичних об'єктів. охочують до геотуризму й с мі дослідники в г лузі н ук про емлю, які ктивно пр цюють н д збереженням і популяриз цією геосп дщини, створюють доступне для розуміння пересічних людей інформ ційно-освітне з безпечення щодо окремих об'єктів і територій.

1. овк. ., цібор . . стосув ння геоінформ ційних технологій в геотуризмі (н прикл ді геологічних п м'яток іровогр дської обл сті) // еоретичні і прикл дні н прямки розвитку туризму т рекре ції в регіон х кр їни: б. н ук. пр ць. іровогр д, 2015. . 220-227.

2. інько . ., $\quad$ в вчук . ., евчук . . уково-пр ктичні й освітні спекти геотуризму // ізичн геогр фія т геоморфологія. . : 5 бріі, 2009. ип. 55. .127-139.

3. інько . . ивчення геотопів геоморфологічного типу хідного оділля для потреб природоохоронного пл нув ння // існ. ьвів. ун-ту. ерія геогр. 2009. ип. 36. . 39-150. DOI: http://dx.doi.org/10.30970/vgg.2009.36.2988

4. еотуризм: пр ктик і досвід : м тері ли міжн родної н укової конференції / ед. . . к кун, . . убняк. ьвів : рти і тл си, 2014. 152 с.

5. Brocx M., Semeniuk V. Geoheritage and geoconservation - history, definition, scope and scale // Journal of the Royal Society of Western Australia. 2007. Vol. 90. P. 53-87. 
6. Carreras J., Druguet E. Geological heritage, an essential part of the integral management of World heritage in protected sites // Geological Heritage: its conservation and management. Lectures presented in the III International Symposium ProGEO on the Conservation of the Geological Heritage (1999. Madrid (Spain)) / D. Barettino, W.A.P. Wimbledon, E. Gallego (Eds.). 2000. P. 95-110.

\title{
REFERENCES
}

1. Vovk, A. M., \& Matsibora, O. V. (2015). Application of geoinformation technologies in geotourism (on the example of geological monuments of the Kirovograd region). Theoretical and applied directions of development of tourism and recreation in the regions of Ukraine. Kirovograd, 220-227 (in Ukrainian).

2. Zinko, J. V., Kravchuk, Y. S., \& Shevchuk, O. M. (2009). Scientific-practical and educational aspects of geotourism. Physical geography and geomorphology, 55, 127-139 (in Ukrainian).

3. Zinko, J. V. (2009). Studying the geotops of geomorphological type of Western Podillia for the purpose of nature protected planning. Visnyk of the Lviv University. Series Geography, 36, 139-150. DOI: http://dx.doi.org/10.30970/vgg.2009.36.2988 (in Ukrainian).

4. Skakun, L. Z., \& Bubniak, I. M. (Eds.). (2014). Proceedings from the International Scientific Conference Geotourism: practice and experience. Lviv: SPF Karty i atlasy, 152 p. (in Ukrainian).

5. Brocx, M., \& Semeniuk, V. (2007). Geoheritage and geoconservation - history, definition, scope and scale. Journal of the Royal Society of Western Australia, 90, 53-87.

6. Carreras, J., \& Druguet, E. (2000). Geological heritage, an essential part of the integral management of World heritage in protected sites. In D. Barettino, W.A.P. Wimbledon, E. Gallego (Eds.), Geological Heritage: its conservation and management (p. 95-110). Lectures presented in the III International Symposium ProGEO on the Conservation of the Geological Heritage, 1999. Madrid (Spain).

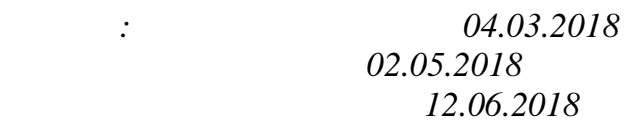

\section{THE CONCEPT OF GEOHERITAGE}

\author{
Oksana Paniv \\ Ivan Franko National University of Lviv, \\ P. Doroshenko St., 41, UA - 79007 Lviv, Ukraine, \\ e-mail: oksanapaniv@ukr.net
}

\footnotetext{
Geoheritage is the inherent element of global natural heritage, which should be preserved for future generations. Scientific information on evolutionary features and processes of our planet is the main value of natural heritage. The significant feature of natural heritage is the human's install of the values, which can change over time.

Geoheritage is someway similar to historical and cultural heritage, as it is not always associated with natural spaces, and in many circumstances geological interest can be closely related to historical and
} 
cultural elements. It is a part of natural heritage of a certain site formed by geodiverse elements with particular geological value, thus worth being protected by present and future generations. Geoheritage may cover both the elements underlying where they were formed and the elements removed from their original location (geological samples collection) with paleontological, geomorphological, mineralogical, petrological or stratigraphical merit.

Geoheritage is the object of geotourism. Geotourism is a comparably new term used to designate a travel devoted to the unique culture and history of any region, a travel carrying and accentuating geographical knowledge of the site, its environment, heritage, culture and prosperity of the local population

Geotourism is closely related to geoheritage protection: numerous geotourist attractions are under the protection of law at the same time. In such cases a special schedule of sightseeing is arranged - the admission to these objects or their specific parts is limited, tourist movement is directed by the explicit and marked routes, the tourist load is controlled, and the other ways to preserve them are applied.

Initiation of the European Association for the Conversation of the Geological Heritage became a remarkable event of international importance. Regional working groups were launched in Europe, and Ukraine is the member of the Central European one.

Key words: geoheritage, geoconservation, geodiversity, geotourism. 